\title{
Peningkatan Kemampuan Motorik Kasar melalui Kegiatan Senam Irama
}

\author{
Anik Wijayanti, Arwendis Wijayanti, Bayu Adi Laksono \\ PG PAUD STKIP Modern Ngawi \\ Jalan Ir Soekarno No. 9 Ringroad Barat Grudo Ngawi Jawa Timur \\ E-mail: Whawawawa383@gmail.com
}

\section{Article Info}

Received September 2019 Accepted Desember 2019 Published April 2020

Keywords: Gross Motor Skills, Activities, Rhythmic Gymnastics, Play Groups, Action Research.

\section{Abstract}

This study aims to describe the increase in gross motor skills through rhythmic gymnastics in the Nurul Iman Padas Ngawi playgroup. The research method used is collaborative classroom action research using a modified model of Kemmis and Mc Taggart which includes four stages, namely planning, action, observation, and reflection. The research subjects were 12 children of the Nurul Iman Padas Ngawi Play Group, consisting of 3 boys and 9 girls. Data collection techniques are carried out through observation, interviews, and documentation study. The data analysis technique in this research is qualitative and quantitative data analysis. The success indicator determined is if at least $75 \%$ or 9 children out of 12 have gross motor skills with very well developed criteria. The results of this study indicate that the process of implementing rhythmic gymnastics activities in improving gross motor skills of children in the Play Group Nurul Iman Padas Ngawi. Rhythmic gymnastics can improve children's gross motor skills by $92 \%$.
\end{abstract}

\begin{abstract}
Abstrak : Penelitian ini bertujuan untuk mendiskripsikan peningkatan kemampuan motorik kasar melalui kegiatan senam irama pada anak Kelompok Bermain Nurul Iman Padas Ngawi. Metode penelitian yang digunakan adalah Penelitian Tindakan Kelas kolaboratif dengan menggunakan modifikasi model Kemmis dan Mc Taggart yang meliputi empat tahapan yaitu perencanaan, tindakan, pengamatan, dan refleksi. Subjek penelitian adalah anak Kelompok Bermain Nurul Iman Padas Ngawi yang berjumlah 12 anak terdiri dari 3 anak laki-laki dan 9 anak perempuan. Teknik pengumpulan data dilakukan melalui observasi, wawancara, dan studi dokumentasi. Teknik analisis data dalam penelitian ini adalah analisa data kualitatif dan kuantitatif. Indikator keberhasilan yang ditetapkan yaitu jika minimal 75\% atau 9 anak dari 12 anak memiliki kemampuan motorik kasar dengan kriteria berkembang sangat baik. Hasil penelitian ini menunjukkan bahwa proses pelaksanaan kegiatan senam irama dalam meningkatkan kemampuan motorik kasar anak kelompok Bermain Nurul Iman Padas Ngawi. Kegiatan senam irama dapat meningkatkan kemampuan motorik kasar anak sebesar $92 \%$.
\end{abstract}

Kata kunci : Kemampuan Motorik Kasar, Kegiatan, Senam Irama, Kelompok Bermain, Action Research. 


\section{PENDAHULUAN}

Anak adalah generasi penerus bangsa yang memegang peranan penting maju tidaknya suatu bangsa, menyadari akan arti penting generasi penerus bangsa yang berkualitas mengharuskan pendidik membekali anak dengan pendidikan yang baik agar anak menjadi manusia seutuhnya dan menjadi generasi yang lebih baik dari pendahulunya. Dalam hal kemampuan motorik terutama motorik kasar anak terkadang mengalami kesulitan dalam melakukan gerak lengan, gerak kaki dan kombinasi gerak lengan dan kaki.

Pendidikan Anak Usia Dini (PAUD) adalah suatu upaya pembinaan yang ditujukan kepada anak sejak lahir sampai usia enam tahun yang dilakukan melalui pemberian rangsangan pendidikan untuk membantu pertumbuhan dan perkembangan jasmani dan rohani agar anak memiliki kesiapan dalam memasuki pendidikan lebih lanjut (UU No.20 Tahun 2003)

Salah satu perkembangan anak yang dapat distimulasi adalah perkembangan motorik. Perkembangan motorik menurut Corbin (dalam Sumantri, 2005) adalah perubahan kemampuan gerak dari bayi sampai dewasa yang melibatkan berbagai aspek perilaku dan kemampuan gerak. Jadi melalui 3 pendidikan anak usia dini perkembangan gerak pada anak dapat distimulasi agar berkembang secara optimal.

Kemampuan motorik kasar adalah kemampuan yang membutuhkan koordinasi sebagian besar tubuh anak. Oleh karena itu, biasanya memerlukan tenaga karena dilakukan oleh otot-otot yang lebih besar (Sujiono, dkk, 2014). Pengembangan gerakan motorik kasar juga memerlukan koordinasi kelompok otot-otot anak yang tertentu yang dapat membuat mereka dapat meloncat, memanjat, berlari, menaiki sepeda roda tiga, serta berdiri satu kaki.

Perkembangan motorik adalah perkembangan pengendalian gerakan jasmaniah melalui kegiatan pusat syaraf, urat syaraf, dan otot terkoordinasi (Hurlock,1978) Pengendalian tersebut berasal dari perkembangan refleksi dan kegiatan massa yang ada pada waktu lahir. Sebelum perkembangan tersebut terjadi, anak akan tetap tidak berdaya. Akan tetapi, kondisi ketidak berdayaan tersebut berubah secara cepat. Selama 4 atau 5 tahun pasca lahir, anak dapat mengendalikan gerakan yang kasar. Gerakan tersebut melibatkan bagian 
badan yang luas yang digunakan dalam berjalan, berlari, melompat, berenang dan sebagainya.

Peraturan menteri pendidikan dan kebudayaan Republik Indonesia Nomor 137 tahun 2014 lingkup perkembangan motorik kasar meliputi kemampuan melompat ke depan dan ke belakang dengan dua kaki, Gerak mengikuti irama, Meniru gerakan senam sederhana sesuai tema( menirukan gerakan kelinci melompat pada tema binatang, gerakan pohon ditiup angin pada tema tanaman).

Berdasarkan hasil pengamatan dan wawancara dengan guru kelas di Kelompok Bermain Nurul Iman Padas, diperoleh beberapa faktor yang menyebabkan kemampuan motorik kasar anak kurang berkembang yaitu (1) Faktor dari dalam diri anak itu sendiri misalnya anak tersebut terlalu pendiam dan malas. (2) Faktor dari gurunya, penyajian kegiatan dalam bentuk gerak sedikit dan monoton. (3) Faktor dari orang tua dan keluarga yang tidak suka olahraga sehingga tidak mengulangi kegiatan motorik kasar yang telah diajarkan oleh guru. (4) Kurangnya alokasi waktu, karena ada lima pengembangan dasar (Nilai Agama dan Moral, Sosial Emosional, Bahasa, Kognitif, Seni).

Atas dasar hal tersebut maka perlu ada suatu kegiatan pembelajaran yang dapat membantu meningkatkan kemampuan motorik kasar. Salah satu kegiatan pembelajaran yang dianggap dapat meningkatkan kemampuan motorik kasar adalah melalui kegiatan senam irama. Senam irama adalah gerakan senam yang dilakukan dalam irama musik, atau latihan bebas yang dilakukan secara berirama (Mardiana, Ade., Purwadi dan Satya, Wira, 2010).

Melalui kegiatan senam irama, anak dapat menggerakkan seluruh anggota badannya, sehingga kemampuan motorik kasarnya akan meningkat. Selain itu, kombinasi antara tangan dan kaki dapat terstimulasi melalui kegiatan senam irama. Selain itu penggunaan musik yang sudah sering didengar oleh anak-anak membuat anak menjadi lebih tertarik untuk melaksanakan kegiatan senam irama. Kegiatan senam irama yang dilakukan secara berulang-ulang bertujuan agar kemampuan motorik kasar anak dapat meningkat dan berkembang. 
Berdasarkan hasil observasi awal yang dilakukan di kelompok bermain Nurul Iman Padas Ngawi sebagian besar anak masih belum berkembang kemampuan motorik kasar, hal tersebut dapat terlihat saat: (1) Anak kesulitan melakukan gerak lengan.(2) Anak mengalami kesulitan melakukan gerak kaki. (3) Anak kesulitan melakukan kombinasi gerak lengan dan kaki. Hal ini diperkuat oleh data yang diperoleh yaitu anak kesulitan melakukan gerak lengan sebanyak 10 anak dari 12 anak (83\%), anak kesulitan melakukan gerak kaki 10 anak dari 12 anak (83\%), anak yang kesulitan melakukan kombinasi gerak lengan dan kaki sebanyak 11 anak dari 12 anak (92\%).

Berdasarkan data di atas kegiatan senam irama ini diperlukan untuk meningkatkan kemampuan motorik kasar. Melalui Kegiatan Senam Irama anak akan merasa senang karena musik yang dipergunakan adalah musik yang sering didengar anak-anak yang, misalnya saja lagu Potong Bebek Angsa, Elang atau lagu-lagu sederhana lainnya yang sesuai dengan tema. Gerakan yang digunakan dalam kegitan senam irama menggunakan gerakan sederhana yang dapat meningkatkan kemampuan otot-otot besar anak sehingga kemampuan motorik kasar anak dapat berkembang.

\section{Kemampun Motorik Kasar}

Kemampuan adalah kecakapan yang terdiri dari tiga jenis kecakapan untuk menghadapi dan menyesuaikan ke dalam situasi yang baru dengan cepat dan efektif, mengetahui atau menggunakan konsep-konsep yang abstrak secara efektif, mengetahui relasi dan mempelajarinya dengan cepat (Slameto,2010)

Ability ( kemampuan, kecakapan, ketangkasan, bakat, kesanggupan) merupakan tenaga ( daya kekuatan) untuk melakukan suatu perbuatan menurut (Chaplin, 1997) sedangkan kemampuan bisa merupakan kesanggupan bawaan sejak lahir atau merupakan hasil latihan atau praktek.

Berdasarkan pemaparan teori di atas dapat diambil kesimpulan bahwa kemampuan adalah kesangguapan yang dibawa sejak lahir untuk menghadapi dan menyesuaikan diri dengan segala situasi.

Motorik kasar adalah gerakan yang banyak menggunakan otot-otot kasar. Sehingga untuk melakukan gerakan motorik kasar, seperti untuk aktifitas berlari, memanjat, melompat atau melempar memerlukan tenaga karena dilakukan oleh otot- otot yang besar (Syaodih, 2015) 
Motorik kasar adalah kemampuan gerak tubuh yang menggunakan otototot besar, sebagian besar atau seluruh anggota tubuh. Motorik kasar diperlukan agar anak dapat duduk, menendang, berlari, naik turun tangga dan sebagainya. Perkembangan motorik kasar anak lebih dulu dari pada motorik halus, misalnya memegang benda-benda yang ukuran besar dari pada ukuran yang kecil. Karena anak belum mampu mengontrol gerakan jari-jari tangannya untuk kemampuan motorik halusnya, seperti meronce, menggunting dan lainlain (Musfiroh, 2014)

Berdasarkan Teori tersebut peneliti menyimpulkan bahwa motorik kasar adalah kemampuan gerak untuk beraktivitas dengan mengunakan otot-otot besar.

\section{Kegiatan Senam Irama}

Senam irama atau disebut juga aktivitas gerak berirama adalah gerakan senam yang dilakukan dalam irama musik, atau pembelajaran bebas yang dilakukan secara berirama (Muhajir, 2017). Aktivitas gerak berirama dapat dilakukan dengan menggunakan alat ataupun tidak mengunakan alat. Alat yang sering digunakan adalah gada, simpai, tongkat, bola, pita, topi dan sebagainya. Secara prinsip antara senam biasa dengan senam irama tidak ada bedanya, hanya saja pada senam irama ditambahkan irama (ritme). Tekanan yang harus diberikan pada senam irama ialah: irama, kelentukan tubuh dan kontinuitas gerakan.

Senam irama adalah senam yang diiringi dengan irama dan gerakannya harus tetap mengikuti irama ( Sutisna dkk, 2004). Senam irama merupakan perpaduan antara gerakan olahraga dan seni tari. Senam irama mengutamakan gerakan yang indah dan dapat dilakukan dengan cara berjalan atau berlari.

Senam irama adalah bentuk-bentuk gerakan senam yang merupakan perpaduan antara berbagai bentuk gerakan dengan irama yang mengiringinya. Misalnya irama, ketukan, tepukan, tambore, nyanyian, musik dan sebagainya (Syarifuddin \& Muhadi,1993).

Keindahan bentuk-bentuk gerakan, menciptakan variasi gerakan, dan membentuk gerakan melalui kombinasi antara berbagai bentuk gerakan dengan irama merupakan tuntutan dalam senam irama. 
Berdasarkan pendapat di atas dapat diambil kesimpulan bahwa kegiatan senam irama adalah bentuk- bentuk gerakan senam yang merupakan perpaduan antara berbagai bentuk gerakan dengan irama yang mengiringi. Gerakan yang dilakukan harus sesuai dan selaras dengan irama yang mengiringinya agar gerakan yang dilakukan terlihat serasi.

Dalam melakukan kegiatan senam irama harus selalu memperhatikan prinsip-pinsip yang dimiliki senam ini, agar dalam melakukan kegiatannya dapat berjalan lancar dan optimal. Adapun prinsip-prinsip senam irama tersebut meliputi irama, kelentukan tubuh dalam gerakan (fleksibelitas) dan kontinuitas gerakan yang (Woerjati, dkk, tanpa tahun).

1) Irama

Dalam melakukan kegiatan senam irama, hal yang paling penting adalah mengenal dan merasakan irama dalam lagu-lagu yang akan digunakan sebagai musik pengiring. Irama dalam sebuah lagu dapat ditentukan dari bunyi bass,yaitu keras dan lambatnya petikan bass, yaitu keras dan lambatnya petikan bass. Ketika seseorang sudah dapat merasakan irama dalam sebuah lagu, maka dengan sendirinya orang tersebut akan merasa senang mengerakan badan. Selain itu, seseorang dapat dengan mudah menyesuaikan irama dengan gerakannya (Woerjati,dkk, tanpa tahun) mendalam nyanyian dibedakan menjadi irama 2/4, 4/4, 3/4, dan 6/8. Penggunaan masing masing irama lagu tersebut dalam kegiatan senam irama berbeda-beda, tergantung latihan-latihan yang sedang dilakukan. Irama lagu yang digunakan pada saat pemanasan akan berbeda dengan irama lagu yang digunakan pada saat latihan inti dan penenangan.

2) Kelentukan tubuh (fleksibelitas)

Kelentukan tubuh (fleksibelitas) dalam senam irama dimaksudkan sebagai kemampuan seseorang dalam menekuk (melipat) dan meliukkan tubuh, sehingga tampak adanya elastisitas dan kelenturan gerakan tubuh. Contoh gerakan yang membutuhkan kelentukan tubuh adalah membungkukkan badan, meliukkan badan kesamping, dan memilin badan. Kelentukan tubuh ini sangat penting dalam kegiatan senam irama agar tidak menimbulkan gerakan gerakan yang kaku (Woerjati, dkk, tanpa tahun). 
3) Kontinuitas gerakan

Berbagai macam gerakan yang dilakukan dalam kegiatan senam irama merupakan suatu kelanjutan. Gerakan satu dengan gerakan selanjutnya adalah suatu rangkaian yang tidak dapat diputus. Gerakan-gerakan yang dilakukan merupakan suatu kesatuan yang yang berkesinambungan mulai dari awal sampai akhir kegiatan (Woerjati,dkk,tanpa tahun).

Berdasarkan uraian di atas dapat disimpulkan bahwa prinsip-prinsip yang terdapat dalam kegiatan senam irama meliputi irama, kelentukan tubuh dalam melakukan gerakan (fleksibelitas) dan kontinuitas gerakan.

Metode mengajar Senam Irama

mengajar yang digunakan pada senam irama memakai sistim Austria dengan pembagian gerakan menjadi tiga bagian, yaitu latihan pemanasan, latihan inti, dan latihan penenangan.( Woerjati, dkk, Tanpa tahun)

Manfaat senam ada dua yaitu mempunyai 1) manfaat fisik, 2) manfaat mental dan sosial. Menurut Mahendra (2000)Adapun penjelasannya adalah sebagai berikut:

1) Manfaat fisik

Senam adalah kegiatan utama yang paling bermanfaat dalam mengembangkan komponen fisik dan kemampuan gerak. Anak yang terlibat senam akan berkembang daya tahan ototnya, kekuatannya, powernya, kelentukan, koordinasi, kelincahan serta keseimbangannya. Kegiatan senam dapat menyumbang pada pengayaan perbendaharaan gerak para pesertanya. Dasar-dasar senam akan sangat baik dalam mengembangkan pelurusan (aligment) tubuh, penguasaan dan kesadaran tubuh secara umum, dan keterampilan-keterampilan senam. Contohnya berdiri dengan postur tubuh yang baik, menggantung dalam posisi terbalik serta menampilkan variasi gulingan secara berturut-turut.Singkatnya kemampuan-kemampuan yang dikembangkan ketika mengikuti senam dapat dianggap membantu anak untuk mempersiapkan diri untuk bisa berhasil pada cabang-cabang olahraga yang lain.

2). Manfaat mental dan sosial

Ketika mengikuti program senam, anak harus dituntut untuk berfikir sendiri tentang pengembangan keterampilannya. Untuk itu anak harus mampu menggunakan kemampuan berfikirnya secara kreatif melalui pemecahan 
masalah-masalah gerak. Dengan demikian anak akan berkembang kemampuan mentalnya.

Kelebihan dan kelemahan Senam Irama

a) Kelebihan dari senam irama adalah a). Gerakanya mudah ditiru, b). Irama senam irama menggunakan lagu anak-anak, jadi sambil senam anak dapat bernyanyi, c). Gerakan-gerakan senam tersebut apabila dilakukan

b) dengan teratur dapat meningkatkan kesehatan dan juga pertumbuhan fisik pada anak.

Kelemahan Senam Irama adalah gerakan-gerakan senam irama sangat bervariasi sehingga sulit bagi anak untuk menghafalkan gerakan pada senam irama tersebut, dalam waktu yang singkat.

\section{METODE}

Penelitian ini dilaksanakan di Kelompok Bermain Nurul Iman, Padas, Ngawi pada bulan Januari-Februari 2019. Penentuan tempat penelitian didasarkan pada hasil pengamatan penelitian terhadap kurangnya kemampuan motorik kasar anak di kelompok bermain Nurul Iman. Penelitian tindakan ini adalah anak kelompok bermain Nurul Iman usia 3-4 tahun yang berjumlah 12 orang yang terdiri dari 9 orang perempuan dan 3 orang laki-laki.

Hasil intervensi tindakan yang diharapkan dari penelitian tindakan yang dilakukan ini adalah meningkatkan kemampuan motorik kasar anak usia 3-4 tahun yang sesuai dengan tindakan yang diberikan pada anak yaitu kegiatan senam irama. Meningkatkan kemampuan motorik kasar anak dapat dilihat melalui beberapa kriteria yakni: pertama peningkatan kemampuan gerak lengan, kedua peningkatan kemampuan gerak kaki, ketiga peningkatan kemampuan kombinasi gerakn lengan dan kaki.

Desain penelitian yang digunakan adalah model spiral dari Kemmis dan Taggart yang memaparkan dasar pelaksanaan penelitian tindakan atau action research. Berdasarkan refleksi, peneliti mendapatkan peningkatan hasil intervensi tindakan dan memungkinkan untuk melakukan perencanaan tindakan siklus selanjutnya. 


\section{HASIL DAN PEMBAHASAN}

\section{Pra Siklus}

Sebelum pemberian siklus, dilakukan penilaian prasiklus untuk mengetahui kemampuan motorik kasar anak. Berikut ini hasil tingkat pencapaian perkembangan anak (TCP). Kemempuan motorik kasar anak kelompok bermain Nurul Iman Padas Ngawi pada prasiklus dapat dilihat pada grafik sebagai berikut:

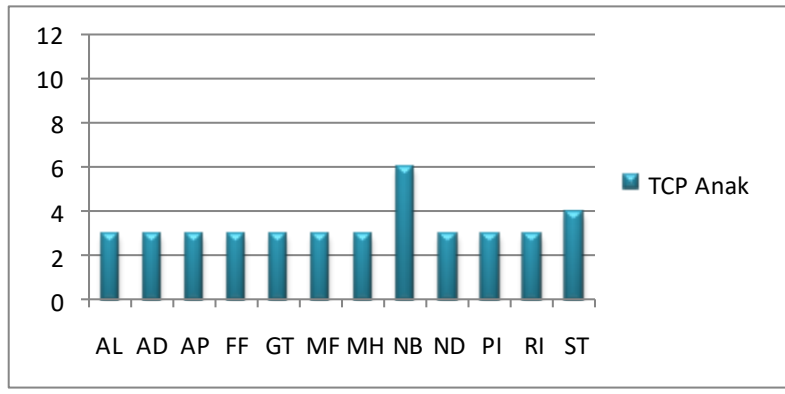

\section{Grafik1. Variabel Kemampuan Motorik Kasar Anak Kelompok Bermain Nurul Iman pada \\ Pra Siklus}

Berdasarkan grafik di atas dengan TCP tertinggi adalah NB dengan jumlah TCP 6 sedangkan TCP terendah diperoleh DF dengan jumlah TCP 3. Hasil asesmen pra siklus menunjukkan bahwa nilai anak berada jauh di bawah target. Target yang disepakati peneliti bersama kolaborator adalah 75\% dari TCP maksimal, artinya TCP minimal anak adalah 9 .

\section{Siklus I}

Berikut ini adalah perbandingan hasil tingkat pencapaian perkembangan (TCP) anak dalam variable kemempuan motorik kasar pada prasiklus dan siklus I 


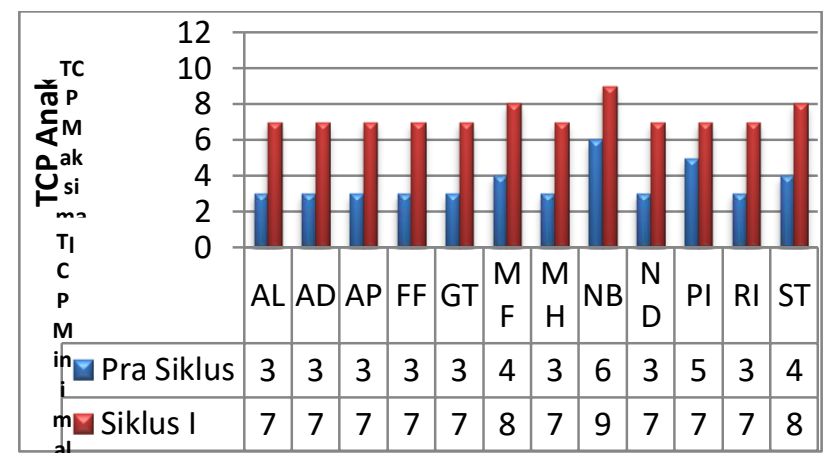

\section{Grafik 2. Variabel Kemampuan Motorik Kasar Pada Anak}

\section{Kelompok Bermain Nurul Iman Padas pada Siklus I}

Grafik di atas menunjukkan bahwa kemampuan motorik kasar pada anak mengalami peningkatan setelah diberi tindakan berupa kegiatan senam irama. Rata-rata TCP anak pada pra siklus sebesar 4 mengalami peningkatan menjadi 8 pada siklus I. Berdasarkan kategori yang ditentukan sebelumnya, rata-rata TCP anak pada siklus I termasuk dalam kategori Mulai Berkembang (MB).

\section{Siklus II}

Peningkatan kemampuan motorik kasar anak terus mengalami peningkatan pada akhir siklus II dapat terlihat pada grafik berikut:

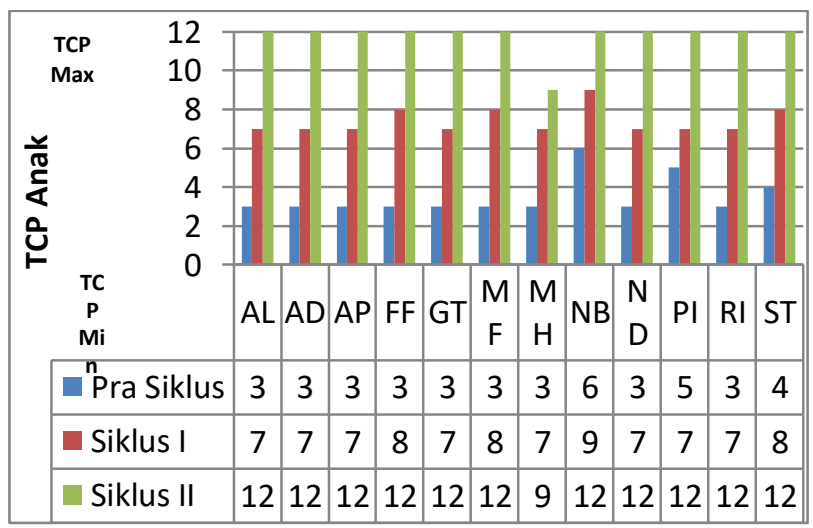

\section{Grafik 3. Variabel Kemampuan Motorik Kasar Pada Anak Kelompok Bermain Nurul Iman Padas pada Siklus II}

Grafik di atas menunjukkan bahwa kemampuan motorik kasar pada anak mengalami peningkatan setelah diberi tindakan berupa kegiatan senam irama. Rata-rata TCP anak pada pra siklus sebesar 4 mengalami peningkatan menjadi 8 pada siklus I dan meningkat lagi 
menjadi 12 pada siklus II. Berdasarkan kategori yang ditentukan sebelumnya, rata-rata TCP anak pada siklus II dan termasuk dalam kategori Berkembang Sangat Baik (BSB).

Pelaksanaan penelitian terdiri dari dua siklus, masing-masing siklus terdiri dari tiga pertemuan, yang bertujuan untuk mendapatkan data valid dan hasil yang signifikan. Setiap siklus terdiri dari perencanaan, pelaksanaan, observasi, dan refleksi. Hasil yang diperoleh pada siklus ini didapat dari data yang berupa lembar observasi. Data lembar observasi tersebut hasilnya digunakan untuk mengetahui peningkatan yang terjadi pada anak. Pada setiap siklus peneliti melaksanakan kegiatan senam irama untuk meningkatkan kemampuan motorik kasar anak kelompok bermain Nurul Iman.

Berdasarkan data observasi pada siklus I masih diperlukan tindakan selanjutnya karena belum mencapai indikator keberhasilan yang telah ditentukan yaitu $75 \%$ dengan kriteria berkembang sangat baik. Kendala yang dihadapi antara lain, gerakan yang dilakukan belum sempurna seperti yang dicontohkan guru, anak-anak sering lupa gerakan senam irama dengan iringan musik dan lagu "Potong Bebek Angsa" karena kurang konsentrasi, anak-anak laki-laki sering ribut sendiri dan mengganggu teman lainnya, beberapa anak masih mengalami kesulitan dalam melakukan kombinasi gerak lengan dan kaki. guru dalam memberikan contoh gerakan tanpa iringan lagu terlalu lama sehingga mengurangi waktu praktek senam irama.

Peneliti harus memperbaiki pada tindakan siklus II yaitu guru memberikan penjelasan pada anak gerakan apa yang harus dilakukan pada saat irama musik tertentu. Misalnya pada irama musik lagu potong bebek angsa gerakan tangan seperti motong. Guru mengingatkan gerakan senam secara lisan, dan melakukan pengulangan gerakan senam agar anak mudah mengingat gerakan senam. Menukar posisi anak laki-laki agar berjauhan dan mengingatkan agar tidak ribut sendiri. Anak-anak yang sudah mahir ditempatkan di depan agar anak yang belum biasa dapat meniru gerakannya. Memberi waktu yang cukup untuk melakukan Senam irama agar anak maksimal dalam melakukan setiap gerakan. Kegiatan senam irama agar anak tidak bosan dan mengenal variasi gerakan diganti dengan irama musik dan lagu "Elang" Yang dikombinasikan dengan irama musik dan lagu "Kupu-Kupu". 
Dengan upaya tersebut diharapkan anak dapat mencapai tingkat keberhasilan sesuai dengan indikator keberhasilan.

Hasil penelitian pada siklus I dan siklus II menunjukkan adanya peningkatan kemampuan motorik kasar melalui kegiatan senam irama pada anak usia dini pada kelompok bermain Nurul Iman Munggut, peningkatan tersebut terjadi pada setiap pertemuan. Kemampuan motorik kasar anak melalui senam irama sebelum tindakan diperoleh data 11 anak atau 92\% yang berada pada kriteria belum berkembang, 1 anak atau $8 \%$ yang berada pada kriteria mulai berkembang, yang berada pada kriteria berkembang sesuai harapan dan pada kriteria berkembang sangat baik belum ada anak yang memenuhinya. Pada siklus I diperoleh 11 anak atau 92\% yang berada pada kriteria mulai berkembang, 1 anak atau $8 \%$ yang berada pada kriteria berkembang sesuai harapan, yang berada pada kriteria berkembang sangat baik belum ada yang memenuhinya.

Berdasarkan data hasil observasi yang diperoleh, dapat diketahui bahwa terjadi peningkatan yang singnifikan pada Siklus II yaitu kemampuan motorik kasar anak pada kelompok bermain Nurul Iman Munggut. Pada siklus II diperoleh 1 anak atau $8 \%$ yang berada pada kriteria berkembang sesuai harapan dan 11 anak atau 92\% yang berada pada kriteria berkembang sangat baik. Penelitian ini dikatakan berhasil karena telah mencapai indikator keberhasilan yang sudah ditentukan yaitu sebesar 75\%. Oleh karena itu, peningkatan kemampuan motorik kasar pada anak usia dini kelompok bermain nurul Iman tidak perlu dilanjutkan lagi, cukup dihentikan pada Siklus II karena telah mencapai indikator keberhasilan yang telah ditentukan.

Pada indikator pertama yaitu gerak lengan, anak dapat melakukan gerak lengan mengalami peningkatan dengan nilai rata-rata Mulai Berkembang (MB) pada siklus I dan meningkat dengan nilai rata-rata Berkembang Sangat Bagus (BSB) pada siklus II. Hal ini sesuai dengan teori yang disampaikan oleh Bambang Sujiono, dkk (2014) mengemukakan bahwa kemampuan motorik kasar adalah kemampuan yang membutuhkan koordinasi sebagian besar tubuh anak. Oleh karena itu, biasanya memerlukan tenaga karena dilakukan oleh otot-otot yang lebih besar.

Sesuai dengan teori (Musfiroh,2014) motorik kasar adalah kemampuan gerak tubuh yang menggunakan otot-otot besar, sebagian besar atau seluruh 
anggota tubuh. Motorik kasar diperlukan agar anak dapat duduk, menendang, berlari, naik turun tangga dan sebagainya. Hal tersebut sesuai dengan indikator gerak kaki ketika melakukan senam irama dengan lagu "Potong Bebek Angsa" pada siklus I dengan nilai rata-rata Mulai Berkembang (MB) dan senam irama dengan kombinasi Lagu "Elang" dan "Kupu-kupu" dengan nilai rata-rata Berkembang Sangat Baik (BSB) pada siklus II.

Selanjutnya sesuai dengan teori (Hurlock,1978) Perkembangan motorik adalah perkembangan pengendalian gerakan jasmaniah melalui kegiatan pusat syaraf, urat syaraf, dan otot terkoordinasi. Hal tersebut sesuai dengan indikator ketiga yaitu kombinasi gerakan lengan dan kaki saat melakukan senam irama dengan iringan lagu.

Berdasarkan data observasi pada pra siklus, siklus I dan siklus II menunjukan bahwa anak yang bernama NB mendapatkan nilai tertinggi. Faktor yang mempengaruhi anak mendapatkan nilai tertinggi yaitu 1) Anak fokus dan konsentrasi menirukan gerakan yang dicontohkan guru, 2) Anak sangat lincah melakukan setiap gerakan, 3) Orangtua sangat mendukung dan sering member motivasi pada anak, 4) anak dapat melakukan gerakan senam irama sesuai yang diharapkan guru.

Anak yang mendapatkan nilai terendah pada pra siklus, siklus I dan siklus II yaitu MF. Faktor yang mempengaruhi anak mendapatkan nilai terendah yaitu 1) Anak suka mengajak temannya bicara sehingga tidak konsentrasi melihat gerakan yang dicontohkan guru, 2) Anak melakukan gerakan semaunya sendiri dan susah diatur.

\section{KESIMPULAN}

Berdasarkan hasil penelitian dan pembahasan dalam penelitian dapat disimpulkan bahwa:

1. Proses pelaksanaan kegiatan senam irama dalam meningkatkan kemampuan motorik kasar anak Kelompok Bermain Nurul Iman Padas Ngawi meliputi : a) gerak lengan; b) gerak kaki; dan c) kombinasi gerak lengan dan kaki yang dilakukan sebanyak 6 pertemuan dalam 2 siklus.

2. Kegiatan senam irama dapat meningkatkan kemampuan motorik kasar anak sebesar 92\%, dengan hasil pada: pra siklus diperoleh $0 \%$ atau belum ada anak dari 12 anak berada pada kriteria berkembang sangat baik, b) siklus I 
diperoleh 8\% atau 1 anak dari 12 anak yang berada pada kriteria berkembang sesuai harapan, c) siklus II diperoleh 92\% atau 11 anak dari 12 anak yang kemampuan motorik kasar berkembang sangat baik.

\section{DAFTAR PUSTAKA}

Chaplin. (1997). Kamus Lengkap Psikologi. Jakarta: Raja Grafindo Pustaka Hurlock, E.B. (1978). Perkembangan Anak. Jakarta: Erlangga

Mahendra, Agus. (2000). Senam. Jakarta: Dirjen Dikdasmen Depdiknas.

Mardiana, Ade., Purwadi dan Satya, Wira. (2010), Materi Pendidikan Jasmani dan Olahraga. Jakarta: Universitas Terbuka

Muhajir. (2017). Pendidikan Jasmani, Olahraga, dan Kesehatan. Indonesia: Kementrian Pendidikan dan kebudayaan.

Musfiroh, T. (2014). Teori dan konsep bermain. Universitas Terbuka, 1-44.

Peraturan menteri pendidikan dan Kebudayaan No. 137 Tahun 2014 Tentang Standar Tingkat Pencapaian Perkembangan.

Slameto. (2010). Belajar dan Faktor-faktor yang Mempengaruhinya, Jakarta: Reneka Cipta

Sujiono, B., dkk. (2014). Metode Pengembangan Fisik. Tangeran Selatan: Universitas Terbuka

Sumantri. (2005). Model Pengembangan Ketrampilan Motorik Anak Usia Dini. Jakarta: Depdiknas

Sutisna, dkk. (2004). Pendidikan jasmani media berolahraga dan berprestasi. Jakarta: Yudistira

Syaodih, E. (2005). Bimbingan di Taman Kanak-kanak. Jakarta: Depdikbud

Syarifuddin, Aip., \& Muhadi. (1993). Pendidikan Jasmani dan Kesehatan. Jakarta: Depdikbud

Undang-Undang RI No 20 Tahun 2003 Tentang Sistem Pendidikan Nasional.

Woerjati Sk, dkk. (Tanpa Tahun). Buku Mata kuliah Senam Irama, Yogyakarta, Program Studi PJKR UNY. 